\title{
Fixing the Broken World With Harmony-Based Leadership
}

\author{
Velimir Srića $^{1}$, Nikola Mićunović \\ ${ }^{1}$ University of Zagreb, Croatia \\ ${ }^{2}$ University of Donja Gorica, Montenegro
}

How to cite this paper: Velimir Srića, Nikola Mićunović. (2020) Fixing the Broken World With Harmony-Based Leadership. International Journal of Humanities, Arts and Social Science, 4(1), 21-28.

DOI: $10.26855 /$ jhass.2020.01.003

Received: March 10, 2020

Accepted: April 1, 2020

Published: April 10, 2020

*Corresponding author: Velimir Srića, University of Zagreb, Croatia.

Email: velimir@velimirsrica.com

\begin{abstract}
The article is based on Velimir Srića's book "In Search of Harmony in a Disharmonious World" and the emerging book "Strategic Harmony: Fixing the Broken World" by Ira Kaufman and Velimir Srića to be published in 2020. The text deals with the challenging conditions in the world and the ways to address them. The proposed solution is Strategic Harmony, based on many years of research and consulting experience. The purpose of the text is to help transform the world to what it can become instead of accepting the present situation as the default. The solution is harmony-based leadership in business and other institutions resulting in sustainable impact on the path to change and organizational harmony. The values are the basic ingredients of successful change management, and the text focuses on win-win, abundance mentality and the balance of Hope (our goals), Head (our thinking), Heart (our feelings) and Hands (our doing), leading to Strategic Harmony.
\end{abstract}

\section{Keywords}

Harmony-based leadership; Value-based organizational change; Fixing the Broken World; Leaders as Catalyzers

\section{Introduction}

The world seems to be broken. Coronavirus pandemy is destroying its societal and economic fabric. Even without that, 824 million people worldwide are starving, 630 million people are homeless, and 40 million people are infected with the HIV virus. The private wealth of the 50 richest people on Earth equals the private wealth of the four billion poorest. Most successful companies are making headlines as colossal failures, and a growing number of respectable politicians, public figures and business executives turn into prime suspects and convicts. We are witnessing mass shootings in schools and in the squares, bloody revolutions, wars and unrest. Despite all the technological innovation, we are unable to deal with the burning issues of health crisis, political instability, suspended economic growth, poverty, injustice, international terrorism, global warming, or mass murders committed by frustrated individuals.

According to Nassim Nicholas Taleb "humanity has never faced such deep social and economic problems, and, at the same time, was equipped with such a low level of understanding of the scope and reach of these problems" (Taleb, 2010).

World is overwhelmed with turmoil, scandals, disasters, economic, political and moral crisis; ecological and ethical trends are negative, and no one has announced a viable vision or plan for reversing them. Due to poor leadership, and the value system of global capitalism, our troubled planet seems to be heading towards a disaster. 
Why is the world broken? The answer lies with the values and beliefs. We are what we believe. Our values lead to behavior and it creates outcomes. If we dislike the outcomes, we must question the values and beliefs.

\section{Methods and Procedures}

\section{What does the world look like?}

There is a story of five monkeys. You hang a bunch of bananas at the cage top and place a ladder nearby. Soon, a monkey climbs the ladder, trying to get some bananas. The moment he touches the ladder, you sprinkle all the animals with ice-cold water and they quickly back off. Soon, another monkey goes for the ladder, just to find out that the ice-cold-water situation is still there. From that moment on, you do not need the sprinkler any more. If a monkey even tries to get close to the ladder, other monkeys are sure to knock him flat (Srića, 2014).

Now, you remove one monkey from the cage and replace him with a newcomer. Seeing the bananas, he tries to reach for the ladder, only to find his ass kicked by all others. You replace another monkey with a new one. If he tries to reach for the ladder, he is severely beaten by all, including the former newcomer. Repeat the procedure until the initial five are removed from the cage. Regardless of the fact that none of the remaining monkeys has ever been sprinkled with ice-cold water, none of them ever tries to get the bananas because, if he did, all the others would immediately stop him. Why? They have learned the way things are done here. And who are they to question the common practice?

This is how values and beliefs led to behavior. The cage metaphor describes nations, tribes, employees, politicians or citizens, who accept the prevailing norms and values without questioning them. Like the Germans under Hitler, the Soviets under Stalin, the Founding Fathers of the USA, many of whom were slave owners, and like the tale of the Emperor who had no clothes. We know what happens when people accept the existing beliefs and values and do not question the inherent contradictions, limitations and shortcomings.

The world is broken and we are trapped in the monkey cage of the old economic, social and political values. Strange, crazy, even outrageous things are constantly taking place around us, why are we treating them as normal.

Most politicians, especially those in power, try to persuade us the world is not broken. In addition, we must learn to live with all the discrepancies, like in a joke about a person, falling from an eighty-story building. As he passes by the fiftieth floor, his phone rings, and a friend asks him: How are you doing today? So far, so good, replies the person.

Now, seriously, the world is broken. The terrorist attacks, bankruptcies, wars and riots are all just the tip of the iceberg; the hypertensions cannot be resolved by the existing values.

We all know that there is a growing gulf between the rich and the poor, and wars break out all over the world. Tensions between the developed and the underdeveloped, the successful and the less successful, create a division that is unprecedented in any period of human history. There are a growing number of political discrepancies, from interest-driven wars to corrupt government officials, from inefficient bureaucracies to inadequate protection of human rights. All that makes people lose faith in democratic institutions. There are growing ecological issues, from the greenhouse effect to water pollution, which make the future look bleak. There are burning moral and ethical dilemmas associated with changing roles of family, religion and nation, cutting deeply into the meaning of existence, freedom, wealth, justice, fairness and legacy.

While most people actually wish for essentially similar things, humanity is confronted with a lack of common vision, distorted value systems, unsuccessful models of government, a poorly educated and misguided population and, above all, bad leadership. Faced with challenges and threats of reason, meaning, ethics, conflict and survival, we seem to be losing the battle for the future. What should we do to reverse the trends?

Some people turn to religion for the answers, as they used to in the past. However, it is not that simple; there are 270 large religious groups in the world, and thousands of smaller ones, and they often quarrel, dispute and disagree. Of course, there is science providing more and more answers to all the provocative questions. However, many believe that scientific revolution and technological development is responsible for at least some of the world problems.

In principle, the state of the world economy and society depends on the prevailing values; we always try to do what is considered right, good, useful, correct, and acceptable. People behave according to their beliefs. That is why a multinational company, faced with a decline in profits, may decide to downsize and lay off workers, moving its production lines to countries with cheap labor; or it may adopt a strategy to invest in workforce 
training in order to increase their loyalty and competence, which, in turn means more innovation, lower costs and higher quality. It all depends on the beliefs shared by the owner and the top management. Likewise, political leaders could decide to increase their impact by honoring a selected bunch of obedient followers, or by promoting reforms and democratic changes. Again, it all depends on what the politicians believe in.

In order to solve its economic problems, a country can try to build up its export capabilities (like China), or develop a despotic system relying on strong army and repression (like the Middle East). Again, it depends on the ruling ideology, norms, perceptions and beliefs. For example, we could jokingly say, like John Steinbeck, that socialism never took root in North America because the poor saw themselves not as an exploited proletariat but as temporarily embarrassed millionaires. Simply stated, if we want to change the behavior, we must first change the perceptions, norms, beliefs and values (Steinbeck, 2003).

Many believe that the world is morally broken because of the free-market ideology. It has reduced all relationships to transactions based on selfish interest. All values have been broken down to customer's choice and the resulting price. Oscar Wilde used to say that cynical people know the price of everything but the value of nothing. Have we all become cynical? We own more things than ever, but somehow, we managed to lower the value of all our belongings, and the same happened to the meaning of life.

In times of amoral behavior, the free market of goods, labor, and ideas might become a source of total lack of freedom. The law of supply and demand affects everything; hence, everything is for sale and can be bought. If you have enough money, you can buy position, power, job, love, justice, health, youth, sport result or verdict. Money can get you out of any trouble. Everything has become an object of trade, and the resulting corruption shows what happens when people start losing dignity, and her majesty Money, the lord of consumption, becomes the absolute ruler. In such an environment, it is the new normal that the best entertainer, athlete, or movie star makes a thousand times more money than the best teacher, educator, doctor or scientist, simply because it reflects the supply-demand relationship.

How did it all happen? Free market and democracy assume morality of all people involved, and the system is, in principle, incapable of controlling the bad people. At the same time, the politicians who should be taking care about the "bad guys", more often than not are connected and networked with them, openly or covertly promoting their interests. As we all know, without financial support from the bad guys, it is virtually impossible to get elected to any important political position. That is why the majority of the world's population tends to distrust politicians and authorities. Nevertheless, people need leaders and role models. In search of the lost values, they either become cynical, or start to incline to the spiritual leadership of strong individuals like the Pope, Sai Baba or Dalai Lama. Again, it reflects the distorted value system.

The main originator of all the global economic and political problems seems to be the present "culture" characterized by lack of morality, abundance of consumerism and greed, obsession with profit and growth, resulting in a huge gap between the rich and the poor. Is it in contrast with the traditional values and beliefs? On the other hand, haven't we always been victims of double morality; to believe in dreams and live in harsh reality; to keep preaching heaven and go on practicing hell.

Economy is broken, how about politics? Even though the free world is fully dedicated to the concept of democracy, there is a growing discontent with bureaucratized and corrupt political elites and parties. We seem to witness a crisis of democratic institutions as well. More people start questioning the mantra that our democracy is perfect - the only problem is its occasionally imperfect functioning. Ask yourself; is any system good if it does not function properly?

As far as the critics are concerned, our democracy is a travesty, spoiled by populism, group interest, political lies, and manipulation with and by the media. Many empty words used to create strong emotions! Whenever there are no solutions to burning problems, the politicians initiate a witch-hunt. The left-wing radicals blame capital owners, managers and employers. The right-wing radicals accuse immigrants and vulnerable ethnic groups. Even the moderate political parties try to find their place in the sun by initiating a dispute between the unions and the employers, or by creating tensions between the public and the private sector. Some blame the government for inefficiency and corruption, or public enterprises for monopolist position and lack of effectiveness. The others think that the sources of all problems are irresponsible corporations.

The intellectual elites are united only in the idea that the greatest responsibility lies on the shoulders of politically illiterate voters. They are blamed for the politicians they elected. As ironically stressed by George Bernard Shaw, democracy guarantees only one thing; we are never ruled better than we deserve. Or, more 
drastically, democracy is when many incompetent vote for a few corrupt. Do we want to continue living in such an environment, or should we opt for better leaders and values that are more balanced?

The time has come to end the double standards and start building a new global economic and political "culture" based on positive values. The key among them is harmony.

\section{Results}

\section{The Harmonious Leadership Model}

My big idea is that, in order for the world to be fixed we need a critical mass of new type of leaders in all segments of our life - politics, business, culture, religion, education, sport, - the harmonious ones. It is only natural that we want to live in harmony with ourselves, with other people, with our goals, thoughts, feelings, hopes and everything that surrounds us.

In principle, the life of every individual consists of many conflicting segments. It is nothing but a series of opposing requirements that need to be balanced and harmonized. First, we have to balance the private and the business sides of our life. Many people are unable to do it right and easily become victims of disharmony. The outcome is either lack of success at work, or a failure with respect to family and friends, or both. We also need to find a proper balance between the individual and the social side of our lives. Other sets of needs and realities have to be balanced if we want to harmonize our life, i.e., the local and the global, the actual and the expected, the planned and the accomplished, the emotional and the rational, the existing and the ideal...

One of the key ingredients of internal harmony is our ability to love and care. Actually, inner harmony is poetically described as a balance of the four H's: Hope, Heart, Head and Hand. First, whatever we do is triggered by Hope, which gives us vision and direction. A passion of Heart follows, providing emotional support and strength to endure. It is reinforced by the stability of our Head, responsible for rational analysis, self-confidence and a propensity to succeed, which, in turn, enables our Hands to work effectively and help us attain goals and make our visions come true. Harmonious people keep all the four H's in harmony. What they Hope for is aligned with what they think in the Head, feel in the Heart and are able to accomplish with their Hands.

What the leader does internally is a lifelong process of self-development. Its goal is to build and improve the leader's harmonious personality. The goal of self-development is to attain and maintain an effective balance of leader's spirituality, cognition, strategy and operating efficiency. I build on the assumption that only leaders with internal harmony can lead and develop harmonious teams. The main outcome of the self-development process is the leader's self-confidence, enhanced willpower and readiness to lead others. The leader's inner balance is a powerful tool in leading other people; its outward appearance is often called charisma, integrity or natural talent for leadership.

The following figure captures the essence of our Harmonious Leadership Model.

Table 1. Harmonious Leadership Model

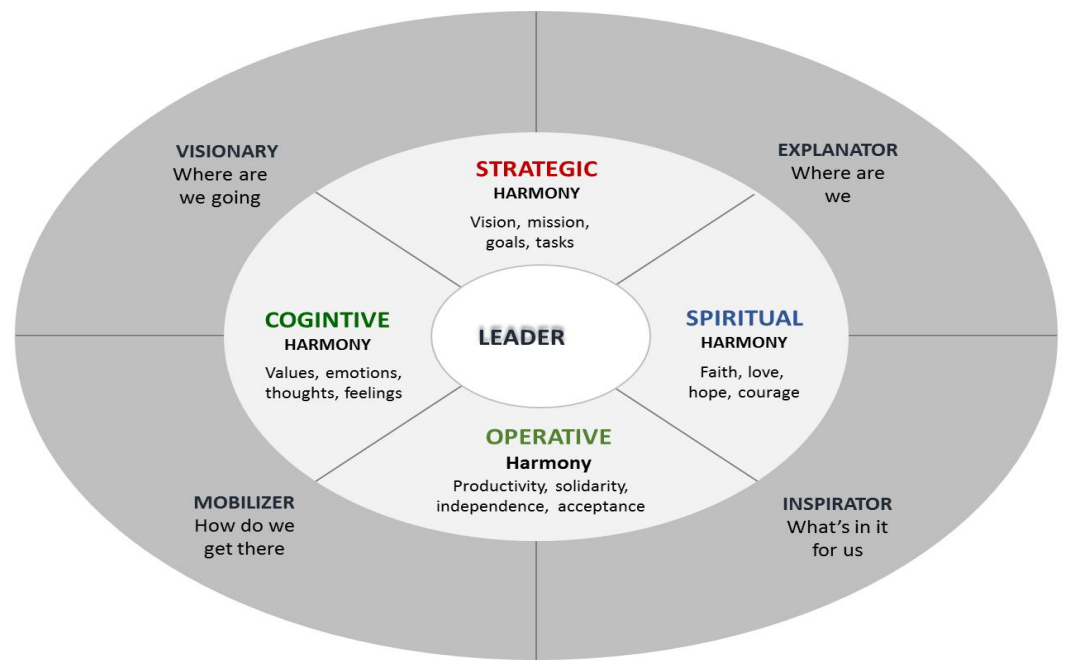

(Srića, 2014) 
The second step of the harmonious leadership process describes how the leader enables his team to win. He must be able to successfully play the four roles of Explanator, Visionary, Mobilizer and Motivator. The task of the Explanator is to define the actual situation (where we are). The task of the Visionary is to explain the future and provide solutions to all problems (where we are going). The task of the Mobilizer is to put the team in motion and ensure unity and efficiency (how to get there). The task of the Motivator is to inspire, provide optimism and energy, as well as to build commitment (what is in it for us).

Have you ever watched a buffet table during a reception dinner? Suppose there is enough food for everybody and no dish ever runs out. How do people behave? Very politely! No one would push in line and the table is surrounded by courtesy and generosity. The abundance mentality prevails, making us all look and behave at our best. Suppose, on the other hand, there is not enough food and all the people around the table are very hungry. A fearful race begins, with elbowing and unscrupulous snatching of a last piece of meat or a cookie. Whoever gets there first puts as much as he can on his plate. The scarcity mentality has taken over, bringing our worst to the surface. However, in principle, it is all in our heads. Our perception runs our behavior. When we think there is a shortage, we become aggressive; we attempt to grab as much as possible, even more than we are able to consume.

I have witnessed similar behavior in both business and government. For example, when budgets are prepared and an overall cut is expected, everyone inflates the demands beyond any real need. On the other hand, if budget growth is expected, the general feeling of scarcity diminishes and most demands become realistic, even modest.

The Visionary should know that any balanced and long-term success depends on our ability to live in harmony with the logic of abundance. To have is not bad, to be able to share is better; to be able to give is the best! Great victories depend on a joint desire to succeed, produce results, and share all gains among members of the team. Business and political victories are long term only if they rely on generous partnership. Instead of fighting over a piece of the existing pie, we must organize to make a larger pie.

Harmonious leaders must understand the abundance/scarcity mentality in order to take the opportunities, and avoid the threats that it brings along.

The scarcity mentality builds up conflicts. It makes us envious, stingy and aggressive, creating a poor environment for cooperation of any kind. On the other hand, the abundance mentality is harmonious and balanced. It leaves room for alliances and partnerships, increases motivation for common goals and provides the competitive environment with a touch of cooperation and friendship.

Good deeds are the best investment for the future. A generous leader is always liked, loved, even adored by his followers. As a harmony-based person, he can teach his teammates that success heavily depends on the unconditional and unanimous support of fellow-workers, based on the abundance mentality as well as on mental and physical generosity.

Throughout our business and private life, we are surrounded by people and things. In principle, people are made to be loved, and things are made to be used. Maybe the world is heading towards a catastrophe because, more and more, we have a tendency to love things and use people.

\section{Discussion}

In one of his lectures, Steven Covey discusses two people with conflicting proposals. After a short argument, the first one says: OK, we disagree, that is for sure. However, if you are ready to give up on your proposal, I will give up on my proposal; and then, could we, together, start searching for a solution that is better than both of our initial proposals?

If accepted by both sides, the effect of such a simple idea may be magical. Whenever we disagree, and each of us wants to beat the other person, imagine that we both decide to abandon the options discussed because they do not offer common victory. Instead of insisting on the conflicting proposals, we decide seek a new solution fully acceptable to both parties. It means that we actually move from a situation with only one winner (Win/Lose) to a situation in which everybody wins (Win/Win).

This is one of the most important values leading to harmony. In order to succeed together, we must shift our attention away from the things that make us disagree and towards our common interest. Just by carefully listening to the other side and taking into consideration their arguments, we may get closer to a harmonious solution, one that could make us all win. If there is no such a solution, we can at least try to settle on one that is close enough. The aim of this process is to provide common benefit and ensure mutual victory.

The common optimum is often possible, but most of the time we do not search for it. Instead, we insist on our 
proposal and want our solution accepted no matter what. Such an attitude is deeply rooted in the common belief that "in order for one to win, the other must lose." The strong always beat the weak and manage to impose their will. The powerful crush the powerless; the rich exploit the poor. It is the natural state of affairs. It is a principle against which we cannot do anything. On the other hand, maybe we can.

Maybe the most recent virus crisis will teach us something. Why, and how? Chinese word CRISIS consists of two ideograms: the first means DANGER, the second means OPPORTUNITY. Most people perceive the Covid 19 as a DANGER manifesting itself in its worst forms. It causes drastic behavior change, quarantine and social isolation. It creates panic, shortages and anxiety. It dramatically reduces economic activity, destroys stock markets and paves the way for recession. Schools, colleges, even kindergartens are closed. Sport events, concerts, competitions and championships are canceled. An overstretched health system is bursting at the seams. Borders are closed, traffic has stopped; airlines, cultural institutions, tourism and the entertainment industry are suffering huge losses. Concerned heads of government hold press conferences on a daily basis to portray the murky reality, offer increasingly drastic measures and increasingly restrictive solutions. Immersed in such a deep crisis, is it at all possible to see the coronavirus as an OPPORTUNITY?

First of all, we can stop and rethink. We can question our values and try to get rid of monkey cage ideas and false myths we are surrounded with. We can ask ourselves whether selfishness, consumerism, alienation and confrontation are good approaches in dealing with our neighbors and our environment. We can also question personal priorities, the meaning of life, work and all our activities. We can better understand the risks of global connectivity and the complexity of all the consequences. We can better grasp the necessary balance between personal freedoms and restrictions that are imposed on us by the interest of common good. We can compare how a deep crisis is addressed by populist democracies and by authoritarian regimes and learn from the mistakes. Finally, we can draw lessons from all this by initiating faster and deeper reforms of the (global and local) political, educational, health, social and, of course, economic systems. We can use the crisis as the pathway to strategic harmony based on better values, leading to more sustainable behavior and better outcomes.

\section{Conclusion}

There is a Zagreb School of Animated films award-winning short film that lasts only two minutes. The whole plot consists of two people, a big one and a small one, running around. Actually, it is a ruthless race. The huge guy keeps pursuing the tiny one, and, from time to time, manages to hit him with a hand, or a stick, or a hammer or whatever he grabs with his big hand. Then, after a minute of merciless violence, they suddenly stop. The small guy asks in the six most common world languages: Why are you hitting me? The big guy replies, again in all the six languages: Because! And the painful struggle for survival continues; the Big one keeps on pounding the Little's head, until THE END fills the screen.

Yes, the big, the strong, the powerful, and the rich are supposed to win, and the small, the weak, the powerless and the poor are destined to lose. This very attitude prevents us from solving most of the political and economic problems in the present world. Whenever the powerful decide not to listen to the powerless, whenever the young and healthy do not obey social isolation rules at the expense of older and sick population, whenever the rich decide not to cooperate with the poor, whenever the polluters don't choose to speak a common language with those who care about the environment, whenever individual members of any group decide to win instead of searching for the common good, the global catastrophe is getting one step closer.

Can we do anything about it? Yes, we can, if we try, even though it will not be easy. The Win-Win behavior is harmonious and ethical, but that is not the main reason why we should stick to it. In the long-run a search for harmony reduces conflicts, increases a sense of unity, stops unreasonable competition, enables joint victories, eventually pays off and proves to be more efficient for all. Of course, it is easier said than done. Also, it is much simpler to do it within a finite team than on the global level.

Even though, in everyday business practice, there are situations in which it is difficult, at times impossible, to find common optimum, it is always useful to try it. The essence of the Win-Win approach is a voluntary search for solutions that make everybody happy.

The use of Win-Win logic in resolving conflict situations seems to be growing. The approach is successfully implemented in companies to resolve strategic discrepancies, or problems between departments. It is also applied in government-employers-trade union negotiations. It may be a basis for modern customer relationship systems, 
successful business partnerships and relations with the public.

It seems that some among the rich, the powerful, and the strong who have no interest in giving up. It will most likely remain so in the short run. However, what happens when everyone's luck changes? Will the poor, the powerless and the weak be generous, once they get control over things? He who does not know how to handle defeat does not deserve a victory. That is why a harmonious leader, one who tries to make sure that everybody wins, eventually is rewarded by a series of personal victories.

Becoming a better leader means to constantly search for a balance of the four H's - Hope, Head, Heart and Hand. They are integrated by the fifth $\mathrm{H}$ - Harmony. Our life is nothing else but a long and winding road taking us back and forth from what we hope for, to what we think, from what we feel to what we do. If all that is in tune, we deserve to be called harmony-based leaders.There is a Zagreb School of Animated films award-winning short film that lasts only two minutes. The whole plot consists of two people, a big one and a small one, running around. Actually, it is a ruthless race. The huge guy keeps pursuing the tiny one, and, from time to time, manages to hit him with a hand, or a stick, or a hammer or whatever he grabs with his big hand. Then, after a minute of merciless violence, they suddenly stop. The small guy asks in the six most common world languages: Why are you hitting me? The big guy replies, again in all the six languages: Because! And the painful struggle for survival continues; the Big one keeps on pounding the Little's head, until THE END fills the screen.

Yes, the big, the strong, the powerful, and the rich are supposed to win, and the small, the weak, the powerless and the poor are destined to lose. This very attitude prevents us from solving most of the political and economic problems in the present world. Whenever the powerful decide not to listen to the powerless, whenever the young and healthy do not obey social isolation rules at the expense of older and sick population, whenever the rich decide not to cooperate with the poor, whenever the polluters don't choose to speak a common language with those who care about the environment, whenever individual members of any group decide to win instead of searching for the common good, the global catastrophe is getting one step closer.

Can we do anything about it? Yes, we can, if we try, even though it will not be easy. The Win-Win behavior is harmonious and ethical, but that is not the main reason why we should stick to it. In the long-run a search for harmony reduces conflicts, increases a sense of unity, stops unreasonable competition, enables joint victories, eventually pays off and proves to be more efficient for all. Of course, it is easier said than done. Also, it is much simpler to do it within a finite team than on the global level.

Even though, in everyday business practice, there are situations in which it is difficult, at times impossible, to find common optimum, it is always useful to try it. The essence of the Win-Win approach is a voluntary search for solutions that make everybody happy.

The use of Win-Win logic in resolving conflict situations seems to be growing. The approach is successfully implemented in companies to resolve strategic discrepancies, or problems between departments. It is also applied in government-employers-trade union negotiations. It may be a basis for modern customer relationship systems, successful business partnerships and relations with the public.

It seems that some among the rich, the powerful, and the strong who have no interest in giving up. It will most likely remain so in the short run. However, what happens when everyone's luck changes? Will the poor, the powerless and the weak be generous, once they get control over things? He who does not know how to handle defeat does not deserve a victory. That is why a harmonious leader, one who tries to make sure that everybody wins, eventually is rewarded by a series of personal victories.

Becoming a better leader means to constantly search for a balance of the four H's - Hope, Head, Heart and Hand. They are integrated by the fifth $\mathrm{H}$ - Harmony. Our life is nothing else but a long and winding road taking us back and forth from what we hope for, to what we think, from what we feel to what we do. If all that is in tune, we deserve to be called harmony-based leaders.

\section{References}

Bennett, N., \& Lemoine, J. (2014). What VUCA really means for you. Harvard Business Review, 92(1/2).

Bon G. (2016), The Crowd - A study of popular mind, Kindle Store, Amazon, Digireads.com (July 1, 2004).

Drucker, P. (1999). Management Challenges for 21st Century New York: Harper Business. Rosabeth Moss Kanter (2001) Evolve, 192-196.

Fromm, E. (2013). To have or to be?. A\&C Black. Bloomsbury Academic; Reprint edition (June 27, 2013). 
Hawkins J. (2013), The Creative Economy: How People Make Money from Ideas, Penguin UK, 2013.

Heimans J., Timms H (2019), The New Power, Anchor.

Kaufman I., Srića V. (2020), Fixing the Broken World with Strategic Harmony, Kitsap Publishing.

Ortega J. (2013), The Revolt of the Masses, Kindle Store, Amazon.

Tom, P. (2010). The Little Big Things-163 Ways to Pursue Excellence. NY: Harper Studio.

Sinek, S. (2009). Start with why: How great leaders inspire everyone to take action. Penguin.

Srića, V. (2014). In Search of Harmony in a Disharmonious World: Leadership Manual for Change Agents and Dreamers. Algora Publishing.

Srića V. (2016), Creativity and Innovation Management, Kindle Store, Amazon, Velimir Srica (February 1, 2016).

Taleb N. (2010), The Black Swan, Kindle Store, Amazon.

Steinbeck, J. (2003). America and Americans and selected nonfiction. Penguin. 